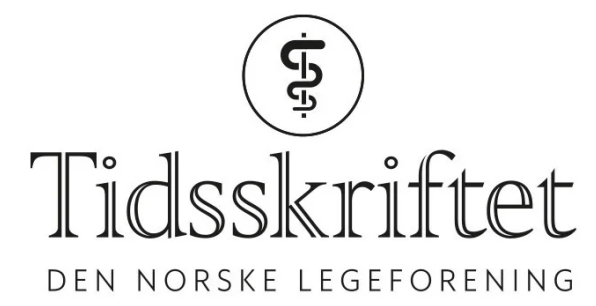

\title{
Immunterapi mot akutt lymfatisk leukemi?
}

FRA ANDRE TIDSSKRIFTER

RUTH HALSNE

ruth@halsne.net

Tidsskriftet

T-celler med modifiserte T-cellereseptorer kan gjenkjenne kreftceller i musemodeller for sykdommen.

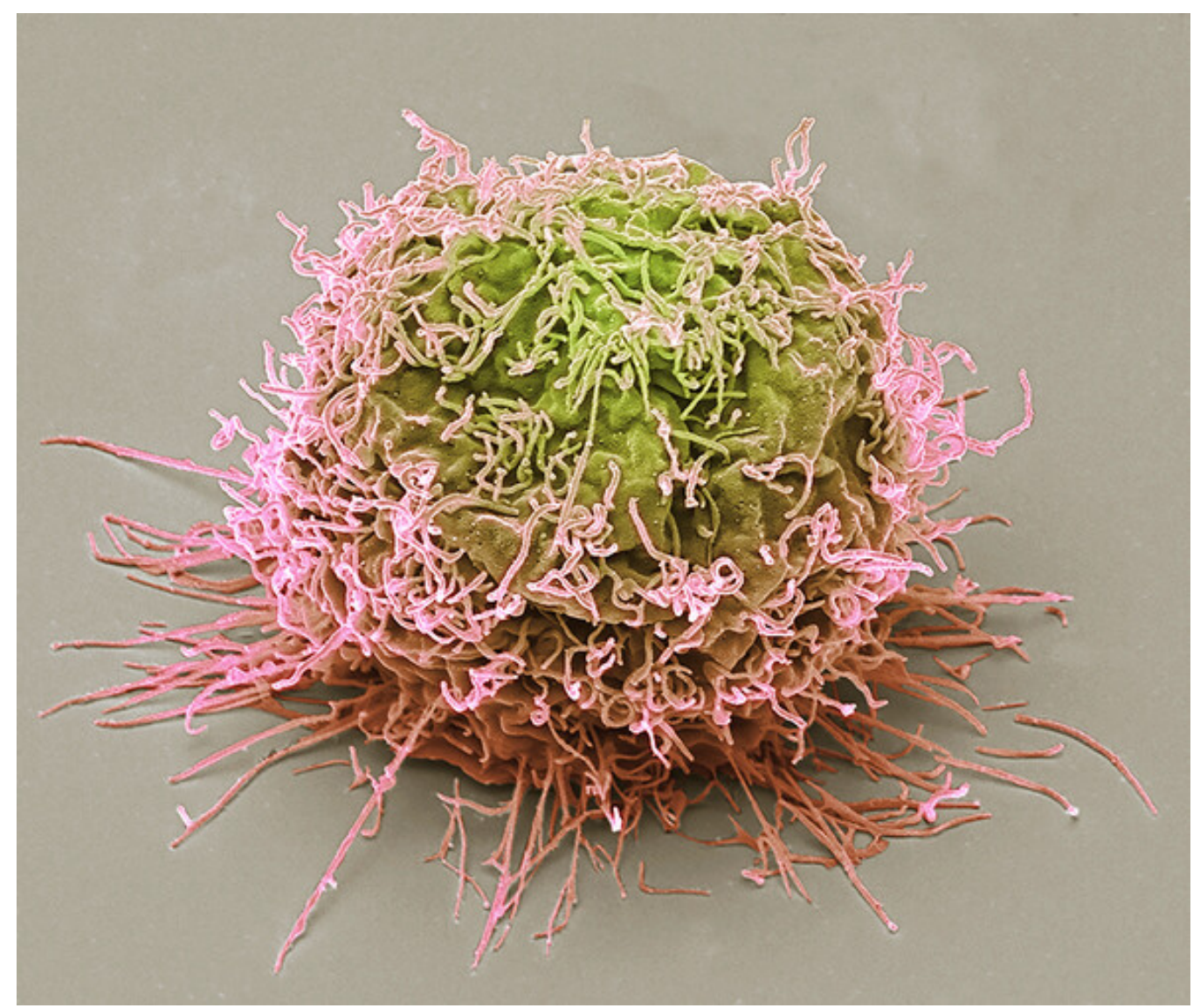

Leukemisk T-celle framstilt ved farget elektronmikrografisk skanning. Illustrasjon: Science Photo Library / NTB 
Enzymet terminal deoksynukleotidyltransferase er en biomarkør for leukemi. Enzymet er et attraktivt mål for kreftbehandling fordi det er høyt uttrykt i kreftceller, mens det kun har et forbigående uttrykk i normale, friske celler. En ny studie viser hvordan dette enzymet kan være viktig i strategien for å utviklet en ny metode for immunterapi mot akutt lymfatisk leukemi (1).

Modifiserte T-cellereseptorer som gjenkjenner den delen av transferaseenzymet som presenteres på kreftcellene, ble karakterisert i cellefors $ø$ k. Deretter ble strategien testet in vivo i mus med etablert leukemi. Ved behandling ble T-celler med modifiserte Tcellereseptorer transplantert i blodstrømmen. Etter 21 dager var musene kreftfrie eller hadde svært redusert kreftforekomst. Både museforsøkene og forsøk med humane pasientcellelinjer viste høy spesifisitet mot kreftcellene.

- Dette er veldig gode nyheter for pasienter som ikke blir kurert av leukemi med stamcellebehandling eller cellegift, sier Viola Lobert, som er cellebiolog og førsteamanuensis ved OsloMet.

- Med denne metoden vil man slippe de uønskede bivirkningene de fleste pasienter får ved cellegift. Det er særlig interessant at det nå finnes en metode med et intracellulært mål, ikke kun ekstracellulært som ved kimerisk antigenreseptor-teknologi, sier hun.

- Utfordringen er at det finnes få gode biomarkører, noe som er en forutsetning for en slik metode. Ofte er proteiner også uttrykt i friskt vev, noe som vil gi bivirkninger. Blodkreft er lettere å kurere enn solide svulster, så det blir spennende å se om denne metoden også kan fungere for andre typer kreft, sier Lobert.

\section{REFERENCES}

1. Ali M, Giannakopoulou E, Li Y et al. T cells targeted to TdT kill leukemic lymphoblasts while sparing normal lymphocytes. Nat Biotechnol 2021;39. doi: 10.1038/s41587-021-01089-x. [PubMed][CrossRef]

Publisert: 25. februar 2022. Tidsskr Nor Legeforen. DOI: 10.4045/tidsskr.22.0005

(C) Tidsskrift for Den norske legeforening 2023. Lastet ned fra tidsskriftet.no 26. april 2023. 